\title{
THE USAGE OF INFORMATION TECHNOLOGY FOR EVALUATION OF ANIMAL WELFARE
}

\author{
— short communcation - \\ Luboš SMUTNÝ*1, Šárka SMUTNÁ*, Jana KINDLOVÁ*, Miloslav \\ ŠOCH*, Václav ŠKEŘ́IK*, Luboš ZÁBRANSKÝ* \\ *University of South Bohemia in České Budějovice
}

\begin{abstract}
: up to date information systems collect data from technological process, facts about production, reproduction and health of animals. On the base of all figures of these measurable values and evaluation of observable characteristics we can do the classification of the total rate of animal welfare. Physical activity of animals is affected by many factors during the day, especially satisfying basic needs, i.e. feed intake, social manifestations, etc. Vitalimeter is recording physical activity of the animal, including the type of movement, standing and lying time, number of leap.
\end{abstract}

Keywords: dairy cows, daily routine, physical activity, welfare

\section{INTRODUCTION}

An essential part of farming is keeping the rules of animal protection, or care for the comfort of animals - so called animal welfare (Šoch, 2005). Many definitions were formulated for welfare. Vebster (1999) states in his publication, that the British Council for the Protection of Farm Animals adopted a definition of welfare specified by so-called five liberties:

- freedom from thirst, hunger and malnutrition

- freedom from discomfort

\footnotetext{
${ }^{1}$ University of South Bohemia in the Czech Budejovice, Faculty of Agriculture, Department of Veterinary Sciences and Product Quality, 370 05, Studentská 13, České Budějovice, Czech Republic, Phone: +420 775754 774, e-mail: lubos.smutny@agrosoft.cz
}

Vol. XVII (2013), no.2 
- freedom from pain, injury and illness

- freedom from fear and pain

- freedom of possible choice of expression of normal behaviour

For the direct monitoring of animal welfare in the stable we can use following selected indicators (Šoch, 2007):

- Physiological parameters expressed by biochemical and physical indicators

- Pathological data demonstrating the reason of morbidity and mortality

- Environment indicators expressed in the form of space intended for use, quality of the climate and lighting, cooling value of environment

- Yield capacity (growth, production, reproduction)

- Ethological studies related to normal and abnormal behaviour

Based on all these observable and measurable characteristics we can implement the assessment of total rate of welfare expressing the state of the animal in three basic areas: physical health, biological functions and behaviour.

According to Moore's Law, computer power doubles every eighteen months (Kaku, 2011). Nowadays we communicate with internet via computers and mobile phones and chips are combined with sensitive sensors. This increase of electronics intervened also in cattle breeding.

Up-to-date information technologies implemented in dairy cattle breeding use the individual approach to each animal. They are based on the electronic identification and measurement of selected physiological parameters such as feed utilization, milk yield and its parameters, body weight and movement activity (Smutný, 1999). All changes in the herd are recorded in the zootechnical programs. Based on these data we can assess both the reproduction parameters and the production results. Veterinary programs then record and evaluate the information about health status of animals (illnesses, vaccination, medical interventions and treatments, reason of elimination or death losses). The system identifying lame dairy cows or vitalimeters that are able to monitor movement activity of animals can help to search for sick animals.

To detect oestrus a number of technical aids were developed. The most advantageous instruments in practice are the electronic devices for measuring physical activity of cows, which are known by various names: pedometer, activometer, vitalimeter (Arney et al., 1994), (At-Taras, et al., 2001),

Vol. XVII (2013), no.2 
(Brehme, et al., 2004), (Liu et al., 1993). Schofield et al. (1991) measured a higher physical activity during oestrus than in other days. Rehout (2003) specified increasing physical activity in oestrus for 2-4 times the value compared to the normal state.

Suitable composition of feed ration and its quality is recommended by feed programs and laboratory analyses. Optimal climate in the stable (temperature, humidity, airflow, lighting, concentration of gases etc.) is also possible to measure and evaluate. It is commonplace for animal welfare to keep the dimensional parameters of stables (beds, standing, barriers, corridors etc.) and technological parameters (fodder filling, water feeding, cleaning of excrements, density of animals, space at the trough, stability of groups). In addition to fulfilling these parameters and positive results from the measurement of physiological values and evaluating software also regular visual monitoring is still necessary. Cows transmit information about their well-being and health with signals and signs. They express it by their behaviour, attitude and physical properties. This "speech" of cows can be used to optimize farming (Hulsen, 2007).

To determine the optimal well-being of dairy cows it would be ideal to monitor their daily regime using electronic equipment and evaluate its deviations. During the day the animals regularly change the alternations of their life manifestations. Animals tend to perform the same activity every day at regular times. Disturbance of their usual daily routine, which animals are used to, causes shortening the rest periods, reduces the usability of received fodder and it all results in the reduction of yield capacity.

The literature shows that the daily regime of the animal in the stable with free stabling is following: twice a day and with unlimited time of eating takes 5-6 hours on average. Within 24 hours the animal drinks approximately 5 to 15 times. In summer cows are drinking regularly throughout the whole day regularly, at night they are restricting fluid intake, whereas in winter it is in reverse. The total time of drinking takes on average 10 minutes a day maximum. Rumination is further important physical manifestation. During this activity the period of rest occurs and it begins usually in 70 minutes after food intake.

The total time of rumination is from $4-7.5$ hours per day, half of this time is in the daytime, the other half at night, which is the same as in animals on pasture. Intervals between separate phases of rumination last only 3-5 seconds. As regards the defecation, it is 10 to 15 times a day while rich feeding. Urinating occurs 6-11 times (Kovalčiková et al., 1984). Then

Vol. XVII (2013), no.2 
relaxation and sleep follows. Cows lie down on average 8-10 times within 24 hours, Voříšková (2001) complements, after two hours of lying they get up and soon lie down again. The longest rest period falls on the night time from 22 p.m. to 4 a.m. Movement is a category of activity which leads to the dislocation of the animal. Intensity of the activity differs according to the way of farming. Loose housing shows the length of the movement about $2 \%$ of the daytime (i.e. about 0.5 hours per day) (Voříšková, 2001). Breeds of the dairy commercial type show higher movement activity compared with the breeding-cows of combined commercial type. Standing time is just over 20 $\%$ of the total daytime (i.e. between 4-5 hours per day) (Voříšková, 2001).

One of the other life manifestations of cattle is comfortable behavior. It has mainly a hygienic significance and consists of a variety of scratching, licking, cleansing the skin and overall care for their and other animals' body surface. It appears most frequently in the early period of the rest (Hrouz, 2000).

\section{MATERIALS AND METHODS}

For monitoring the daily routine of dairy cows we selected a stable in Petrovice, company DZV Nova a.s. (650 dairy cows mainly of Holstein breed). We chose 6 cows that were gravid and without health problems. Monitoring carried out permanently for 24 hours (from 8 a.m.) and the activity of dairy cows was recorded in one-minute intervals. It was necessary to compare the actual daily routine of cows with the above mentioned theory. To monitor the dairy cows' daily routine using the electronic devices we selected vitalimeters. Our objective was to determine whether these devices were able to describe the daily routine of the animals. For this purpose we used the technology of vitalimeters of company Agrosoft Tabor and a software of company FARMSOFT, which was created in cooperation of companies FARMTEC and Agrosoft Tabor. Vitalimeters are hung on the necks of cows, while the number of movements per hour is recorded. Each hour is divided into 240 segments of 15 seconds. Each moving during this segment is recorded. Data from vitalimeters are transmitted via antenna receivers of vitality to a computer and they are evaluated every hour.

\section{RESULTS AND DISCUSSIONS}

Values measured by monitoring of cows correspond with the above mentioned theory in the following areas: eating, number of drinking,

Vol. XVII (2013), no.2 
rumination, defecation, urination and standing. The periods of rest were on average 13 hours a day, which corresponds to the claim Arney (1994), which states that under normal conditions the cows spend 9-14 hours resting during the day. The longest interval of lying was recorded in time from $23 \mathrm{~h}$ to $03 \mathrm{~h}$ in the morning. Number of lying down and getting up was more frequent compared with the literature, i.e. 20-25 times. Deviation from the above mentioned theory is apparently caused by milking three times a day. Move / walking / was estimated to be about 1 hour. The length of moving in loose housing is reported to be about 0.5 hours a day (Voříšková, 2001). Measured value - one hour (or 48-65 minutes) confirms Voříšková (2001) with the walked distance about 200-300 m. The results of vitalimeters were displayed in the graphs.

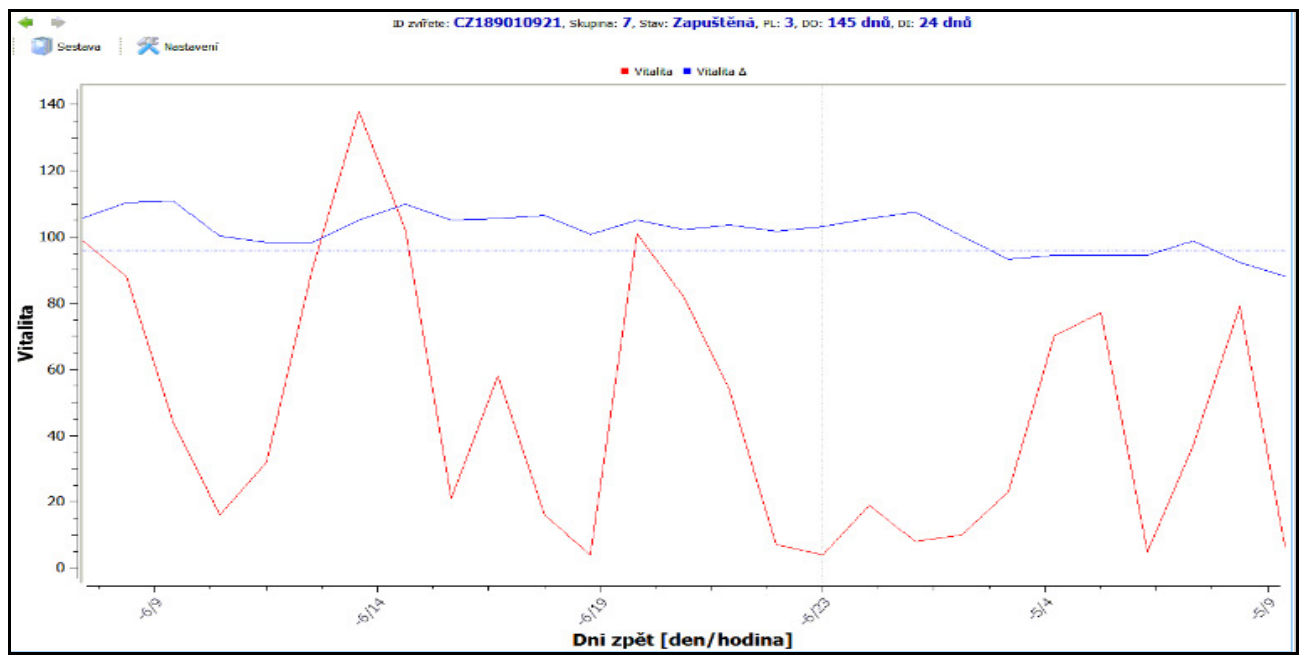

Figure 1. Daily movement activity

Figure 1 shows the course of physical activity within one day. These results show an increased activity at the time of leaving the parlor, milking and return back, as well as the fodder filling and subsequent food intake. Figure 2 shows the course of lactation with a daily recording of physical activity. On the 36th and 59th day oestrus occurred and the physical activity increased by $200 \%$.

For even more precise determination of oestrus the graph of movement activity can be combined with a graph of milk production. As the Figure 3 shows, during the oestrus the milk yield significantly decreased.

Vol. XVII (2013), no.2 


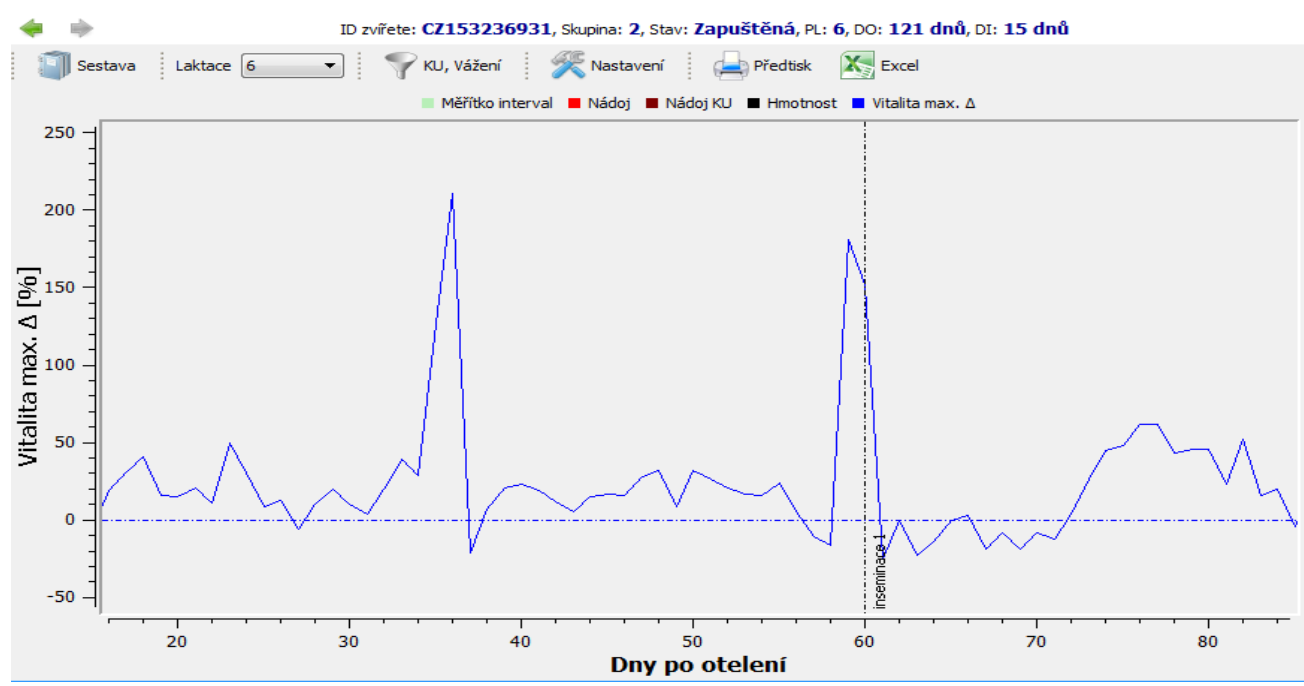

Figure 2. Movement activity during lactation

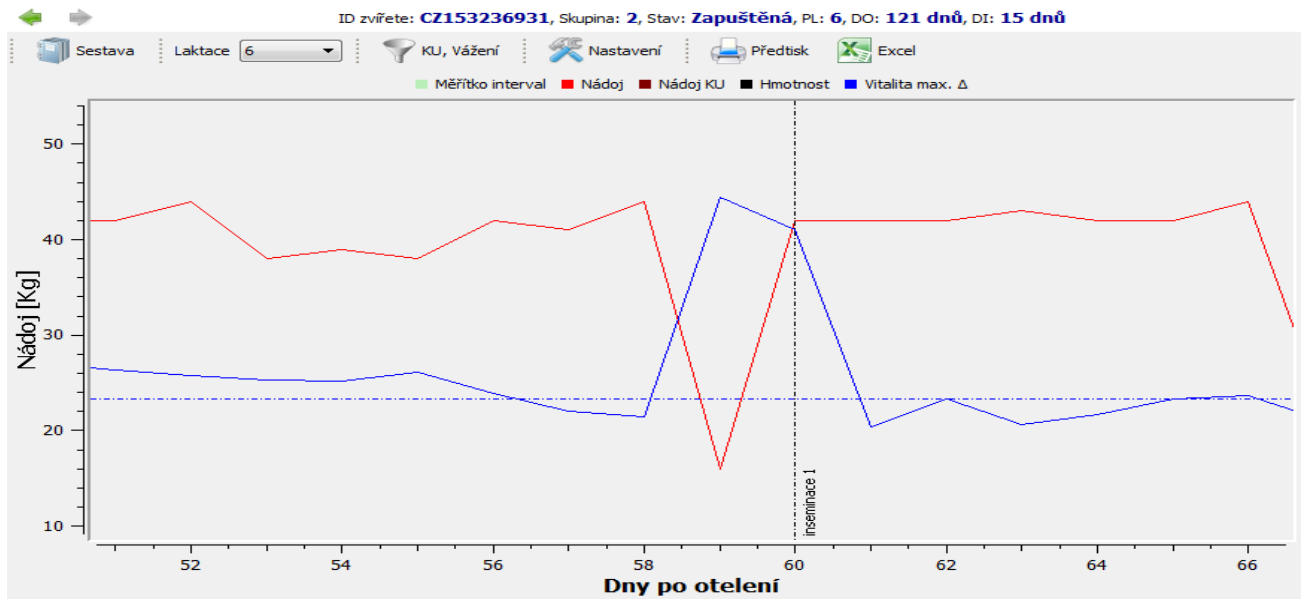

Figure 3. Activity and milk production

\section{CONCLUSIONS}

The comparison of the results of cows' observations and data from vitalimeters indicate that vitalimeters are able to register an increased movement which corresponds with the actual increased mobility of dairy cows, but they do not display individual standing up and lying down, nor any jumps. Nevertheless it will be possible to record these movements using an accelerometer, which will be a part of the new vitalimeter. Contemporary

Vol. XVII (2013), no.2 
vitalimeters reliably detect the occurrence of oestrus. Decreasing of total movement activity may indicate health problems. The period of rumination could be detected by the microphone. We are solving the development of a new vitalimeter in the frame of the project NAZV No. QJ1210144. This device will be used to precise monitoring of movement activity of animals, particularly cattle. Unlike existing systems for monitoring physical activities focused only on monitoring step frequency and evaluation of estrus incidence in dairy cows, this device will be able to watch also a time range of movement, standing, lying and jumps. This extends significantly the possibilities of using the data obtained to refine the identification not only the estrus incidence, but also health disorders and disruptions of the overall welfare.

\section{ACKNOWLEDGEMENTS}

This paper was written during realization of the project NAZV QJ1210144 and GAJU 020/2013/Z.

\section{REFERENCES}

1. Arney, D.R., Kitwood, S.E. \& Philipps, C.J.C. (1994). The increase in activity during oestrus in dairy cows. Appl. Anim. Behav. Sci. 40, 211218.

2. At-Taras, E.E. \& Spahr, S.L. (2001). Detection and characterization of oestrus in dairy cattle with an electronic heatmount detektor and an electronic activity tag. J. Dairy Sci. 84, 792-798.

3. Brehme, U., Stollberg, U., Holz, R. \& Schleusener, T. (2004). Sichere Brunsterkennung mit sensorgestutzten ALT-Pedometern. Landtechnik 59 (4), 230-231.

4. Hrouz, J. (2000). Ethology of farm animals. Mendelova Zemědělská a lesnická univerzita. Brno. 185 s., ISBN 80-7157-463-5.

5. Hulsen, J. (2007). Cow signals. How to understand the speech of cows. Profi Press s.r.o., Praha. ISBN 978-80-86726-44-1.

6. Kaku, M. (2011). Physics of the Future: How Science will Shape Human Destiny and our Daily Lives by the Year 2100. Doubleday. New York. LCCN 2010026569.

7. Kovalčiková, M. \& Kovalčik K. (1984). Ethology of cattle. PRÍRODA Bratislava. $232 \mathrm{p}$.

Vol. XVII (2013), no.2 
8. Liu, X. \& Spahr, S.L. (1993). Automated electronic aktivity measurement for detection of oestrus in dairy cattle. J. Dairy Sci. 76, 2906-2912.

9. ̌nehout, V. (2003) The current problem of breeding, farming and health of cattle and livestock production. České Budějovice: Jihočeská univerzita, p. $100-104$.

10. Schofield, S.A., Philips, C.J.C. \& Owens, A.R. (1991). Variation in milk production, activity rate and electrical impedance of cervical mucus over the oestrus period of dairy cows. Anim. Reprod. Sci. 24, p. $231-248$.

11. Smutný, L. (1999). Information systems for individual care for dairy cows. Technické trendy 1/1999,: 26-27.

12. Šoch, M. (2005). Influence of environment on selected indicators of cattle welfare.Vědecká monografie. Zemědělská fakulta, Jihočeská univerzita v Českých Budějovicích. 288 p. ISBN 80-7040-742-5.

13. Šoch, M. (2007). Animal welfare and civilized society. Přednáška. Zemědělská fakulta, Jihočeská univerzita v Českých Budějovicích.

14. Voř́íšková, J. (2001). Ethology of farm animals. České Budějovice, Jihočeská univerzita. 2 - 67, ISBN 978-80-7394-298-4.

15. Webster, J. (1999). Welfare - well-being of animals or sober sermon about paradise. Nadace na ochranu zvírat, Praha. 264 p. ISBN 80-2384086-X.

Vol. XVII (2013), no.2 